\title{
Antioxidant Activities of n-Hexane Soluble and Insoluble Fraction, Ethyl Acetate Soluble and Insoluble Fraction from Ethanol Extract of Sambung Nyawa Leaf (Gynura procumbens (Lour.) Merr.)
}

\author{
Purwantiningsih*, Retno Murwanti, Lukman Hakim \\ Department of Pharmacology \& Clinical Pharmacy, Faculty of Pharmacy, Universitas Gadjah Mada
}

\begin{abstract}
There were many plants containing flavonoids which can function as antioxidant. Antioxidant can be used to decrease the mortality rate caused by degenerative and infectious diseases. This study aims to determine the antioxidant potency of $n$-hexane soluble and insoluble fraction, ethyl acetate soluble and insoluble fraction, and the ethanol extract antioxidant activity of Sambung Nyawa leaf (Gynura procumbens (Lour.) Merr.). The ethanol extract of G. procumbens leaves was obtained by maceration using $70 \%$ ethanol then fractionated using hexane and ethyl acetate to obtain the n-hexane soluble fraction, n-hexane insoluble fraction, ethyl acetate soluble fraction, and ethyl acetate insoluble fraction. The antioxidant activity study of ethanol extract, n-hexane soluble, and insoluble fraction, ethyl acetate soluble, and insoluble fraction of $G$. procumbens was carried out using DPPH (2,2- diphenyl-1-picrylhydrazyl) method to evaluate its free radical scavenging activity with a comparison of vitamin $\mathrm{C}$. The antioxidants activity was expressed as $\mathrm{IC}_{50}$ value. The IC 50 value for vitamin C and ethanol extract of G. procumbens leaves were $2.41 \mu \mathrm{g} / \mathrm{ml}$ and $200 \mu \mathrm{g} / \mathrm{ml}$. On the other hand, the n-hexane soluble and insoluble fraction had an IC 50 value of $78 \mu \mathrm{g} / \mathrm{ml}$ and $34 \mu \mathrm{g} / \mathrm{ml}$, while ethyl acetate soluble and insoluble fraction had the potency as an antioxidant with an $\mathrm{IC}_{50}$ value of $419 \mu \mathrm{g} / \mathrm{ml}$ and $151 \mu \mathrm{g} / \mathrm{ml}$, respectively. Based on the results obtained, the antioxidant potency of $G$. procumbens ethanol extract and their fraction were successively of $n$-hexane insoluble fraction $>n$-hexane soluble fraction > ethyl acetate insoluble fraction > ethanol extract $>$ ethyl acetate soluble fraction.
\end{abstract}

Keywords: Gynura procumbens; flavonoid; fractionation; antioxidant activity

\section{INTRODUCTION}

Indonesia's high biodiversity provides various types of plants that can be used as antioxidant agents. The presence of antioxidant activity from various plant sources can be utilized in preventing the increase of degenerative diseases. Flavonoid compounds are reported to have antioxidant activity (Trease and Evan, 1989; Narayana, 2001). Antioxidants can help the body control the oxidation process and can prevent or reduce the risk of various diseases. Antioxidant activity arises because of the presence of a phenolic hydroxyl group in its molecular structure that is capable of capturing free radicals, a species that performs oxidation reactions in cells (Kumaran and Karunakaran, 2006).

Antioxidants from synthetic ingredients provide side effects that are quite harmful to health, especially causing cancer (Hernani and Rahardjo, 2005). Therefore, it is necessary to look for sources of natural antioxidant that are safer to develop. Chemical compounds classified as an antioxidant and can be found in plants, including polyphenols, bioflavonoids, vitamin $\mathrm{C}$, vitamin $\mathrm{E}$, beta carotene, catechins, and resveratrol (Hernani and Rahardjo, 2005).

\footnotetext{
*Corresponding author: Purwantiningsih
}

Email : purwantiningsih@ugm.ac.id
Leaves of Gynura procumbens (Lour.) Merr. (G. Procumbens) contains various components, including flavonoids, unsaturated sterols, triterpenes, polyphenols, and essential oils (Pramono and Sudarto, 1985). The results of other studies reported that this plant contains flavonoids, tannins, saponins, steroids, triterpenoids, chlorogenic acid, caffeic acid, vanillic acid, cucumber acids, p-hydroxybenzoic acid (Suganda et al., 1988) whereas the results of qualitative analysis by thin-layer chromatography method conducted by Sudarsono et al., (2002) detected the presence of sterols, triterpenes, phenolic compounds, polyphenols, and essential oils. Sugiyanto et al., (2003) also stated based on research conducted that in the polar fraction of the leaves of $G$. procumbens plant, there were three flavonoids in the flavone and flavonol classes. Research by Idrus (2003) stated that $G$. procumbens contains sterols, sterol glycosides, quercetin, kaempferol-3-0-neohesperidose, kaempferol-3-glucoside, quercetin-3-0-rhamnosyl (1-6) galactoside, quercetin-3 -0-rhamnosyl (1-6) glucoside.

Flavonoid compounds were reported to have antioxidant activity (Trease and Evan, 1989; Narayana, 2001). Research related to the antioxidant activity of $G$. Procumbens by Harun and 
Syahri (2002) who reported that the water extract of $G$. procumbens leaves was reported to have an antioxidant and hepatoprotective effect. The results of Widyaningsih's research (2010) showed that ethanol extract of $G$. procumbens leaves had the ability to capture free radicals at all treatment concentrations of $120-480 \mu \mathrm{g} / \mathrm{ml}$ and obtained an Effective Concentration-50\% value (EC-50) for a sample of $379.21 \mu \mathrm{g} / \mathrm{ml}$ while the standard (rutin), the IC-50 value was 2-10 $\mu \mathrm{g} / \mathrm{ml}$.

The presence of flavonoid compounds in the flavone and flavonol form in G. procumbens leaves allows for antioxidant effects from $G$. procumbens. This study was done to examine the antioxidant effect of ethanol extract, n-hexane soluble and insoluble fraction, ethyl acetate soluble and insoluble fraction of $G$. procumbens and determined the IC-50 with the comparison of Vitamin C using DPPH (2,2- diphenyl-1picrylhydrazyl) method. N-hexane soluble fraction, n-hexane insoluble fraction, ethyl acetate soluble fraction, and ethyl acetate insoluble fraction obtained from fractionation of ethanol extract of $G$. procumbens. The ethanol extract was obtained by maceration using 70\% ethanol and continued with fractionation using n-hexane, ethyl acetate, and water. The results of this study were expected to provide scientific data on the antioxidant activity of n-hexane soluble and insoluble fraction, ethyl acetate soluble and insoluble fraction from the ethanol extract of $G$. procumbens leaves and contribute to the development of the natural product as an antioxidant.

\section{METHODOLOGY \\ Materials}

The main ingredient used in this study was Gynura procumbens (Lour.) Merr., obtained from B2P2T02T (Center for Research and Development of Traditional Medicine and Medicinal Plants), Tawangmangu, Central Java. The sample was collected and determined at B2P2T02T in September 2017.

Extraction and fractionation materials: ethanol, methanol, aquadest, ethyl acetate, and nhexane were purchased from Sigma (St. Louis, MO, USA). Other chemicals include standard vitamin C purchased from Sigma (St. Louis, MO, USA). Sodium hydrogen carbonate was purchased from BDH Supplies Laboratory, UK, while potassium acetate, aluminum chloride, Folin Ciocalteu-reagent and 2,2-diphenyl-1-picrylhydrazyl (DPPH) were purchased from Sigma (St. Louis, MO, USA).

\section{Preparation of n-Hexane Soluble and Insoluble Fraction, Ethyl Acetate Soluble and Insoluble Fraction from The Ethanol Extract of $G$. procumbens Leaves}

The dried sample was obtained by washing the fresh leaves with running water and was then dried in an open space without being exposed to direct sunlight. The drying process was continued in an oven with a maximum temperature of $70^{\circ} \mathrm{C}$. After drying, the dried sample was blended, sieved using a flour sieve with a size of B40 to get a homogeneous powder size. Powder of $G$. procumbens leaves was put into glassware. A total of $300 \mathrm{~g}$ powder was soaked with $1 \mathrm{~L}$ solvent $(70 \%$ ethanol p.a.) for one day while stirring occasionally, and the extract was then separated from the insoluble part by filtering using filter paper. The extraction was repeated for 7 times using $500 \mathrm{~mL}$ solvent of each. All macerate was collected, and the extract was evaporated by rotary evaporator. The condition for evaporator was adjusted at $90 \mathrm{rpm}$, the vacuum pressure of 0.4-0.5 $\mathrm{kPa}$, while the temperature was set at $60{ }^{\circ} \mathrm{C}$. Evaporation was done until the extract weight was constant or all of $70 \%$ ethanol was not present so that a concentrated extract of $G$. procumbens was obtained. Organoleptic extracts were observed, and the yield was calculated using equation 1 .

The ethanol extract was then fractionated with n-hexane and ethyl acetate. Ethanol extract $(13.5 \mathrm{~g})$ was dissolved in $10 \mathrm{ml}$ of distilled water and put in 5 tubes, $2 \mathrm{ml}$ of $\mathrm{n}$-hexane was added to each tube and was then vortexed and centrifuged (3500 rpm). Extraction using n-hexane was carried out for 2 times; the $n$-hexane soluble and insoluble fraction was separated and collected in a separate tube. The fraction was then evaporated in a water bath at a temperature of $50{ }^{\circ} \mathrm{C}$ and flowed with nitrogen gas. The ethyl acetate soluble and insoluble fraction was made with the same procedure but the n-hexane was replaced with ethyl acetate.

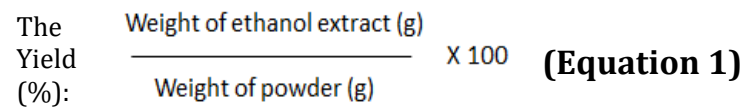 \\ Determination of Antioxidant Activity Using DPPH Method}

The antioxidant activity of ethanol extracts and the four fractions also vitamin $\mathrm{C}$ standard were measured in terms of the ability to make DPPHradical stabilization. The antioxidant activity was 


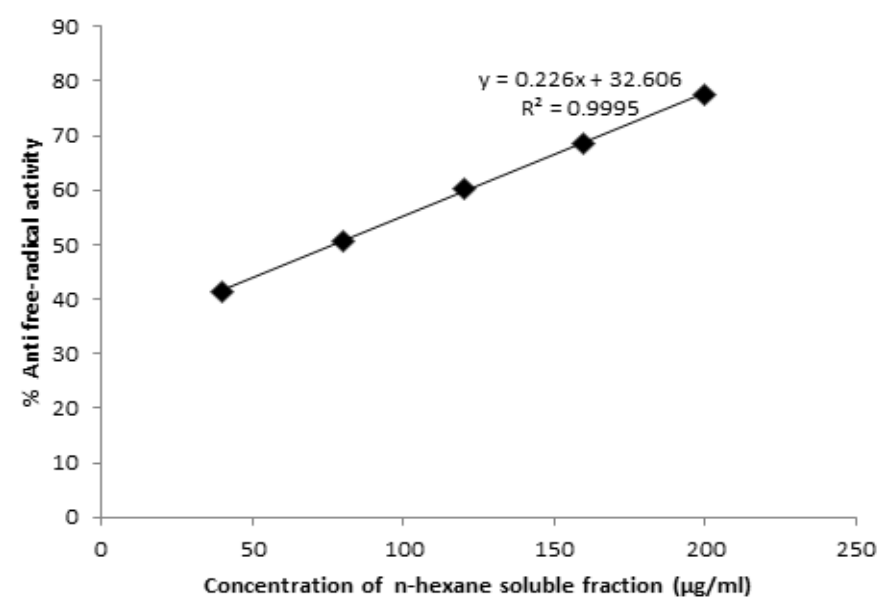

Figure 1. The relationship between concentrations of $n$-hexane soluble fraction and percentage of free radical capture using DPPH method.

Table I. The observation results of extracts organoleptic

\begin{tabular}{lllll}
\hline Extract & Shape & Color & Smell & Taste \\
\hline Ethanol extract of G. procumbens leaves & Thick & Dark green & Typical & Bitter \\
\hline
\end{tabular}

performed using a method that has been published by Kumaran and Karunakaran (2006) with modifications. Ethanol extracts and all four fractions were dissolved in methanol solvent and diluted at concentrations ranging from 0.04-0.5 $\mathrm{mg} / \mathrm{ml}$. DPPH solution (100 $\mu \mathrm{L} ; 0.23 \mathrm{mM})$ was filled in 96 microplate wells and then added a sample or standard solution $(100 \mu \mathrm{L})$. After 30 minutes incubation at $37^{\circ} \mathrm{C}$, absorbance was measured at a wavelength of $517 \mathrm{~nm}$ using a microplate reader. In control well contains $100 \mu \mathrm{L}$ of DPPH solution and $100 \mu \mathrm{L}$ of methanol as blank. Antioxidant activity the ethanol extract and all of four fractions also Vitamin C standard was determined according to the equation 2 :

\section{Antioxidant activity $(\%)=[1-($ As $/$ Ac $)] \times 100$ (Equation 2)}

Where As was the absorbance of the test sample and Ac was the absorbance of the positive control. All data in this study are expressed as mean \pm SD (n $=3$ ).

\section{Data Analysis}

The IC-50 value was calculated from the linear regression equation of the relationship between the percentage of free radical capture versus the concentration of the ethanol extract of G. procumbens or its fraction and was then compared the potency.

\section{RESULTS AND DISCUSSION}

Maceration was carried out according to the reference from the Ministry of Health of The Republic of Indonesia in 2000. The results of the concentrated extract obtained were $63.95 \mathrm{~g}$. The yield of the G. procumbens ethanol extract was $21.06 \%$, this was the ratio of the extract weight produced with the initial weight of the dried sample (303.67 g). Organoleptic examination of extracts was carried out by observing using ordinary eyes, including the shape, color, smell, and taste (Table I). The concentrated extract was then fractionated to produce the soluble and insoluble $\mathrm{n}$-hexane fraction, also the soluble and insoluble ethyl acetate fraction. The four fractions and the ethanol extract were then tested for antioxidant activity using DPPH method.

\section{DPPH Activity Test}

DPPH activity test was carried out on nhexane soluble and insoluble fraction, ethyl acetate soluble and insoluble fraction, and ethanol extracts of G. procumbens also vitamin C standard. DPPH method was selected as a test method for antioxidant activity because it was easy, fast, simple, sensitive, and needed a little sample. DPPH activity test used the IC-50 value as a parameter to determine the concentration of antioxidant compounds that can inhibit $50 \%$ oxidation. The smaller of the IC-50 value, it means that the extract or compound has the higher of antioxidant activity. 


\section{Purwantiningsih}

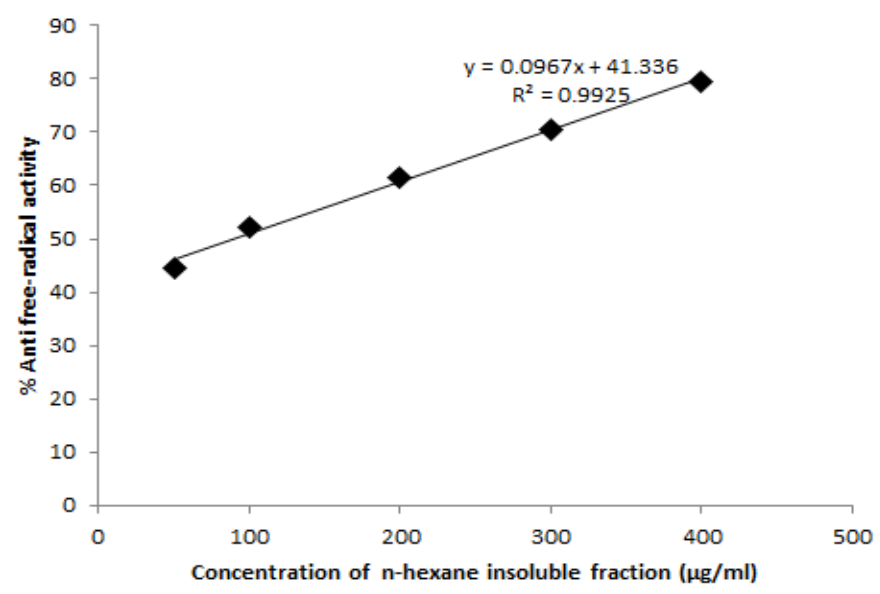

Figure 2. The relationship between concentrations of n-hexane insoluble fraction with a percentage of free radical capture using DPPH method.

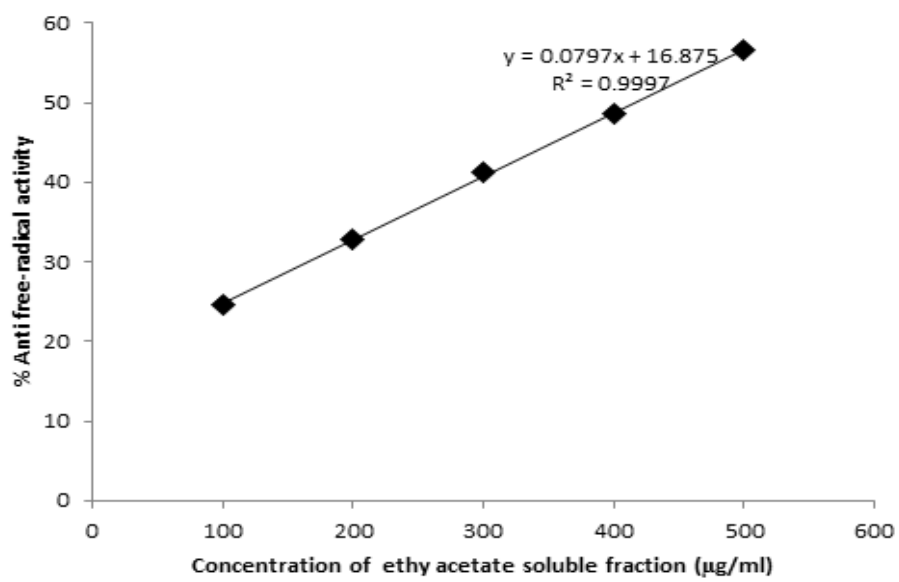

Figure 3. The relationship between concentrations of ethyl acetate soluble fraction with a percentage of free radical capture using DPPH method

Vitamin $\mathrm{C}$ has antioxidant activity with an IC-50 value of $2.41 \mu \mathrm{g} / \mathrm{ml}$ (data are not shown). The DPPH activity test results of the n-hexane soluble and insoluble fraction are shown in Figure. 1 and 2, for the ethyl acetate soluble and insoluble fraction, are shown in Figure. 3 and 4, while for the ethanol extract in Figure. 5. The results showed that the fraction had an inhibition potency of free radicals and the IC-50 values obtained was $78 \mu \mathrm{g} / \mathrm{ml}$ for $\mathrm{n}$ hexane soluble fraction and $34 \mu \mathrm{g} / \mathrm{ml}$ for $\mathrm{n}$-hexane insoluble fraction. The IC-50 values of ethyl acetate soluble and insoluble fractions were $419 \mu \mathrm{g} / \mathrm{ml}$ and $151 \mu \mathrm{g} / \mathrm{ml}$, respectively. On the other hand ethanol extracts had an IC-50 of $200 \mu \mathrm{g} / \mathrm{ml}$ and the IC-50 data values were summarized in (Table II). Based on these results, the antioxidant potency of the five fractions was the n-hexane insoluble fraction $>$ n-hexane soluble fraction $>$ ethyl acetate insoluble fraction $>$ ethanol extract $>$ ethyl acetate soluble fraction. The n-hexane insoluble fraction turned out to have the potential as the most prominent antioxidant among the five extract test. Antioxidant activity was often associated with the flavonoid content, unfortunately, there was no determination of the extract flavonoids content so that it cannot be correlated.

Based on the level of antioxidant intensity, the n-hexane insoluble fraction had the very strong potency with IC-50 $<50 \mu \mathrm{g} / \mathrm{ml}$, while n-hexane soluble fraction was strong with IC-50 $<50-100$ $\mu \mathrm{g} / \mathrm{ml}$. The antioxidant potency of ethyl acetate insoluble fraction was medium with IC-50 in the range of $100-250 \mu \mathrm{g} / \mathrm{ml}$, while the ethanol extract and ethyl acetate soluble fraction were weak with IC-50 values > $200 \mu \mathrm{g} / \mathrm{ml}$. Study of antioxidant potency using DPPH method has been carried out to determine the potential of various plants which are estimated to have flavonoid content and 


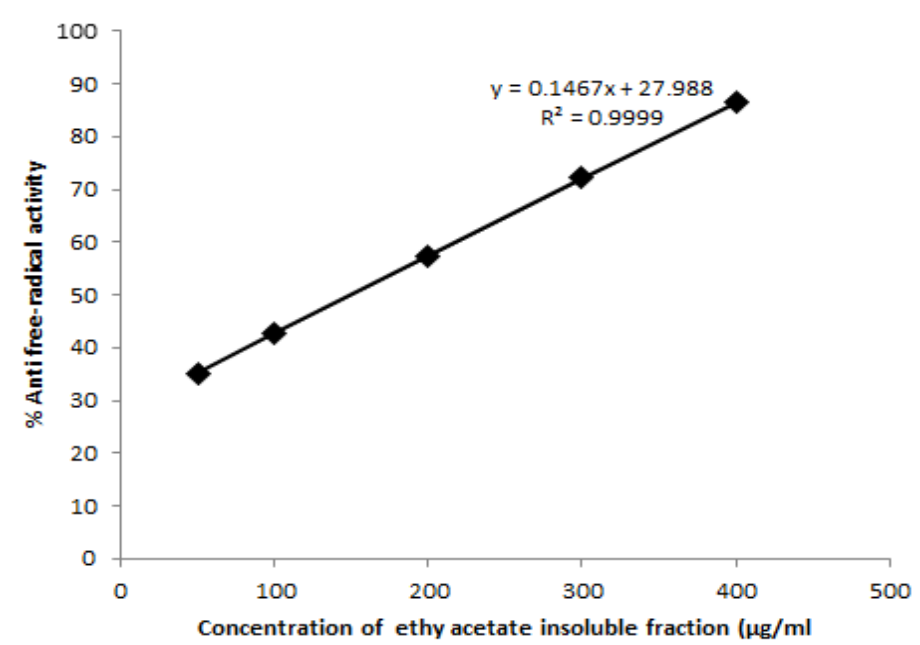

Figure 4. The relationship between concentrations of ethyl acetate insoluble fraction with a percentage of free radical capture using DPPH method.

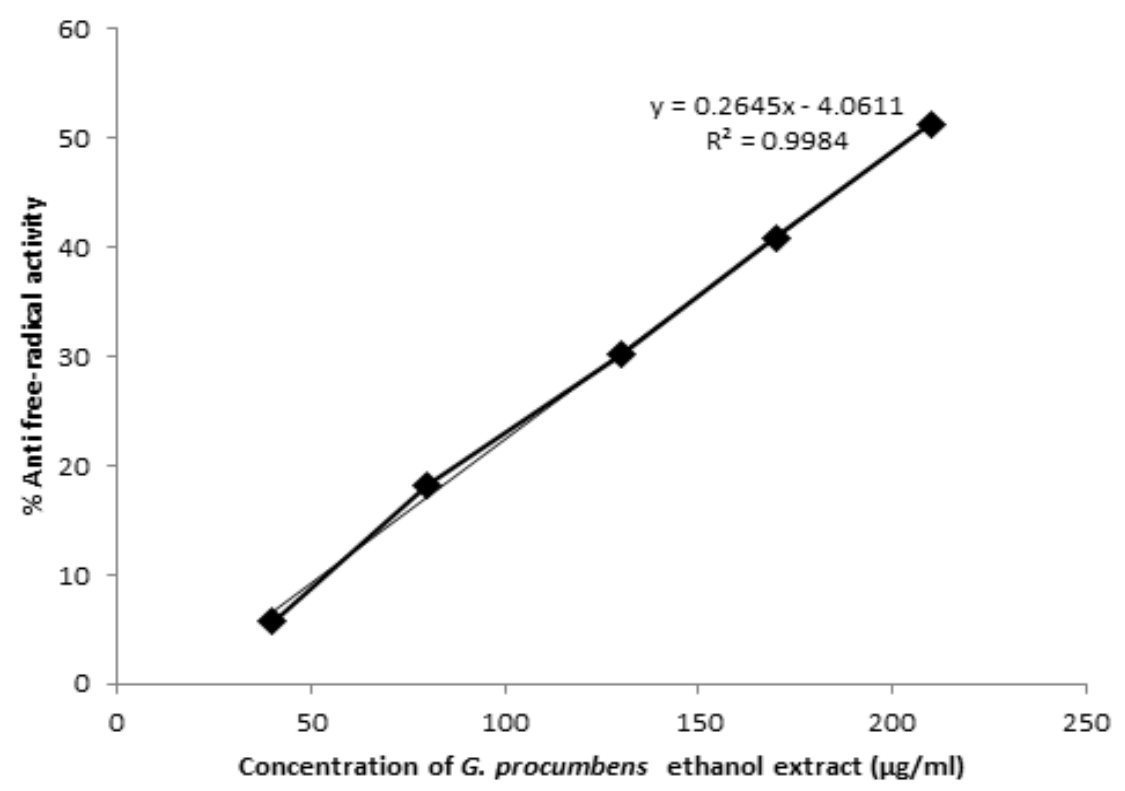

Figure 5. The relationship between concentrations of G. procumbens ethanol extract and the percentage of free radical capture using DPPH method.

Table II. The IC-50 values of G. procumbens ethanol extract fraction, the test results using the DPPH method.

\begin{tabular}{clc}
\hline No & \multicolumn{1}{c}{ Type of Faction } & IC-50 Score $(\boldsymbol{\mu g} \mathbf{g} \mathbf{m l})$ \\
\hline 1 & Standard (Vitamin C) & 2,41 \\
2 & G. procumbens ethanol extract & 200 \\
3 & n-Hexane insoluble fraction & 34 \\
4 & n-Hexane soluble fraction & 78 \\
5 & Ethyl acetate insoluble fraction & 151 \\
6 & Ethyl acetate soluble fraction & 419 \\
\hline
\end{tabular}

predicted to have antioxidant effects. The ability of flavonoid compounds in capturing free radicals is related to the presence of phenolic hydroxyl groups in their structure that function as donors of hydrogen atoms in these radicals (Heim et al.,
2002). DPPH accepts electrons or hydrogen radicals to form the stable diamagnetic molecules. The interaction of antioxidants with DPPH either with hydrogen radical on DPPH or the electron transfer will neutralize the free radical character of 
DPPH (Sunarni, 2005). The difference in the ability of these antioxidants to DPPH free radicals is caused by the ability to transfer different hydrogen atoms (Nakiboglu et al., 2007). In this study, it was known that n-hexane insoluble fraction had a higher antioxidant activity effect compared to ethyl acetate soluble fraction using vitamin $\mathrm{C}$ as a standard. This was consistent with the study by Teoh et al., (2016) that the antioxidant potency of n-hexane was higher than ethyl acetate fraction with n-hexane IC-50 value was $2.44 \mathrm{mg} / \mathrm{ml}$, and ethyl acetate IC-50 value was $4.16 \mathrm{mg} / \mathrm{ml}$.

Sambung nyawa or $G$. procumbens leaves have long been used by the community to treat various diseases in several countries, including Indonesia, Malaysia, Vietnam, Thailand, and China. Some are consumed raw or cooked. In Indonesia, for example, this plant has been used traditionally to treat kidney disease, while in Vietnam, it is used to reduce fever. The use of $G$. procumbens in Thailand is quite extensive and is usually used for the treatment of rheumatism, inflammation and various infectious diseases caused by viruses (Rosidah et al., 2008; Bodeker et al., 2009; Wiart, 2006; Kaewseejan et al., 2015; Krishnan et al., 2015).

Various studies had been conducted regarding its potential for the treatment of various degenerative diseases such as cardioprotective and antihypertensive activity, antihyperglycemic, anticancer, antimicrobial and antiinflammation activity and also as antioxidant (Hoe et al., 2007; Abrika et al., 2013; Algariri et al., 2013; Nisa et al., 2012; Rahman and Asad, 2013; Akowuah et al., 2009).

G. procumbens in addition to having the ability to free radical capture also had the ability to reduce ferric ions which certainly illustrates its potential as an antioxidant (Akowuah et al., 2009; Kaewseejan et al., 2015). The antioxidant potency of $G$. procumbens was shown by the high inhibitory potency of the ethanol extract (the DPPH inhibition was 58\%) when compared with several other plants tested (Maw et al., 2011). G procumbens was also reported as a potential antioxidant by using various antioxidant test methods such as xanthine oxidase, trolox equivalent, and beta carotene linoleic acid assay (Rosidah et al., 2008). G. procumbens also showed activity in inhibiting lipid peroxidation (Luerang et al., 2010) and can reverse the process of increasing lipid peroxidation in plasma (Akowuah et al., 2009). Other researchers (Krishnan et al., 2015) revealed that the root extract of $G$. procumbens had the highest antioxidant activity when compared to other parts of the plant. Rosidah et al., (2008) suggested the potency of antioxidants $G$. procumbens may be supported by its phenolic content.

\section{CONCLUSION}

$\mathrm{N}$-hexane soluble and insoluble fraction, ethyl acetate soluble and insoluble fraction had the potential as antioxidants with IC-50 values of 78 $\mu \mathrm{g} / \mathrm{ml}, 34 \mu \mathrm{g} / \mathrm{ml}, 419 \mu \mathrm{g} / \mathrm{ml}$, and $151 \mu \mathrm{g} / \mathrm{ml}$, respectively. While ethanol extract had an IC-50 value of $200 \mu \mathrm{g} / \mathrm{ml}$. Based from these results the antioxidant potency of the five consecutive $n$ hexane insoluble fraction $>$ n-hexane soluble fraction $>$ ethyl acetate insoluble fraction $>$ ethanol extract $>$ ethyl acetate soluble fraction.

\section{ACKNOWLEDGMENTS}

The authors wish to acknowledge the Faculty of Pharmacy UGM for providing research funding to researchers through the grant program of the Faculty of Pharmacy's basic research support in 2017 with the contract number of UGM/FA/1675.a/M/05/01.

\section{REFERENCES}

Abrika, O.S.S., Yam, M.F., Asmawi, M.Z., Sadikun, A., Dieng, H., and Hussain, E.A. 2013. Effects of extracts and fractions of Gynuraprocumbens on rat atrial contraction. J. Acupunct . Meridian Stud. 6: 199-207.

Akowuah, G.A., Mariam, A., and Chin, J.H. 2009. The effect of extraction temperature on total phenols and antioxidant activity of Gynura procumbens leaf. Pharmacogn. Mag. 4: 8185.

Algariri, K., Meng, K.Y., Atangwho, I.J., Asmawi, M.Z., Sadikun, A., Murugaiyah, V., et al., 2013. Hypoglycemic and anti-hyperglycemic study of Gynura procumbens leaf extracts. Asian Pac. J. Trop. Biomed. 3: 358-366.

Bodeker, G., Salleh, H and Shekar, S.C. 2009. Health and Beauty from the Rainforest: Malaysian Traditions of Ramuan. Kuala Lumpur: Editions Didier Millet Pty Ltd.

Harun, N. and Syahri, W., 2002, Aktivitas Antioksidan Ekstrak Daun dewa (Gynura procumbens (Lour.) Merr. dalam Menghambat Sifat Hepatotoksik Halotan dengan Dosis Subanestesi pada Mencit, Jurnal Sains dan Teknologi Farmasi. 1(2): 6370.

Hoe, S.-Z., Kamaruddin, M.Y., and Lam, S.-K. 2007. Inhibition of angiotensin- converting enzyme activity by a partially purified fraction of Gynura procumbens in spontaneously hypertensive rats. Med. Princ. Pract. 16: 203-208. 
Heim, K.E., Tagliaferro, A.R. and Bobilya, D.J., 2002, Flavonoid Antioxidants: Chemistry, Metabolism and Structure Activity Relationships, J. Nutr, Biochem. 13: 572-582.

Hernani and Rahardjo. M., 2005, Tanaman Berkhasiat Antioksidan Penebar Swadaya, Jakarta, 1-20, 62-63.

Idrus, A.A., 2003, Global Information Hub onIntegrated Medicine-Gynura procumbens (Lour..) Merr.., http://www.nhiondemand.com/ diakses pada 19 Juni 2013.

Kaewseejan, N., Sutthikhum, V., and Siriamornpun, S. 2015. Potential of Gynura procumbens leaves as source of flavonoid-enriched fractions with enhanced antioxidant capacity. J. Funct. Foods. 12: 120-128.

Krishnan, V., Ahmad, S., and Mahmood, M. 2015. Antioxidant potential in different parts and callus of Gynura procumbens and different parts of Gynura bicolor. I Biomed Res. Int. 2015:1-7.

Kumaran A, and Karunakaran R. 2006, Antioxidant and free radical scavenging activity of an aqueous extract of Coleus aromaticus. Food Chem. 97: 109-114.

Luerang, A., Thammasarn, K., Sittiwet, C., Naowaratwattana, W., Chaichanadee, S., Puangpronpitag, D., etal. 2010. Evaluation of nutritional value and Antioxidative properties of the medicinal plant Gynura procumbens extract. Asian J. Plant Sci. 9: 146-151.

Maw, S.S., Mon, M.M., and Oo, Z.K. 2011. Study on antioxidant and antitumor Activities of some herbal extracts. World Acad. Sci. Eng. Technol. 75:450-455.

Nakiboglu, M., Urek, R.O., Kayali, H.A. and Tarhan, L., 2007, Antiokxidant capacities of endemic Sideritis sipylea and Origunum sipyleum from Turkey, Food Chem. 104: 530-635.

Nisa, F., Hermawan, A., Murwanti, R., and Meiyanto, E. 2012. Antiproliferative Effect of Gynura procumbens (Lour.) Merr. Leaves etanolic extract on 7,12-dimethyl benz (a) antracene induced male rat liver. Adv. Pharm. Bull. 2: 99-106.
Narayana, K.R., 2001, Bioflavonoid Classification, Pharmacological, Biochemical Effect and Therapeutical Potential, Indian J. Pharmacol. 33: 2-16.

Pramono, S., and Sudarto, B., 1985, Skrining Fitokimia Daun Dewa (Gynura procumbens (Lour..) Merr..) yang Diduga Berkhasiat sebagai Antikanker, PPPT-UGM, Lembaga Penelitian UGM, Yogyakarta.

Rahman, A., and Asad, M. 2013. Chemical and biological investigations of the Leaves of Gynura procumbens. Int. J. Biosci. 3:36-43.

Rosidah, Yam, M., Sadikun, A., and Asmawi, M. 2008. Antioxidant potential of Gynura procumbens. Pharm. Biol. 46: 616-625.

Sudarsono, Gunawan, D., Wahyuono, S., Donatus, I.A., Drajat, M., Wibowo, S.and Ngatidjan., 1996, Tumbuhan Obat, Hasil Penelitian, Sifat-Sifat dan Penggunaan, PPOT UGM, Yogyakarta, 68-70.

Suganda, A., Sudiro, I. and Ganthina, 1988, Skrining Fitokimia dan Asam Fenolat Daun Dewa (Gynura procumbens (Lour.) Merr.), Simposium Penelitian Tumbuhan Obat III, Universitas Indonesia, Jakarta.

Sugiyanto, Sudarto, Meiyanto E, Nugroho AE. and Jenie U.A., 2003, Aktivitas antikarsinogenik senyawa yang berasal dari tumbuhan. Indonesian J. Pharm. 14(4): 216-225.

Sunarni, T., 2005, Aktivitas Antioksi dan Penangkap Radikal Bebas Beberapa Kecambah dari Biji Tanaman Famili Papilionaceae, Indonesian J. Pharm. 4: 34-39.

Teoh, W.Y., Wahab, N.A., Richardson, J.S.M. and Sim, K.S., 2016, Evaluation of Antioxidant Properties, Cytotoxicity and Acute Oral Toxicity of Gynura procumbens (Compositae), Sains Malays. 45(2): 229-235.

Trease, G.E., and Evans, W.C., 1989, Pharmacognosy, 419-420, ELBS. Low Priced Edition Oxford.

Wiart, C. 2006. Medicinal Plants of Asia and the Pacific. Boca Raton, FL: CRC Press.

Widyaningsih, W., 2010, Uji Aktivitas Antioksidan Ekstrak Etanol Daun Dewa (Gynura procumbens) dengan Metode DPPH (1,1difenil-2-pikril hidrazil), Prosiding Seminar Nasional KosmetikaAlami, Yogyakarta, 109115. 